\title{
Schwarzenegger endorses stem-cell push
}

Jonathan Knight, San Francisco

After months of silence, California's Republican governor, Arnold Schwarzenegger, lent his backing on Monday to the state's ballot initiative to fund embryonic stem-cell research. Supporters of the plan, on which Californians will vote in two weeks, had become increasingly optimistic that it would pass following a string of endorsements from newspapers and public figures, as well as a continuing lead in the polls. The governor's approval now adds to their confidence.

The measure, known as Proposition 71, would pump $\$ 300$ million a year for a decade into the ethically charged research. Its supporters say the investment would pay large dividends both in treatments for intractable diseases and in healthcare savings for the cashstrapped state. Opponents call those claims speculative at best, and point to the ethical difficulties of taking cells from embryos that are either discards of fertility treatments or created specifically for cell harvesting.

The Proposition 71 campaign turned up the heat on 24 September with a string of 30 second television spots in which researchers, patients and celebrities such as the actor Michael J. Fox, who has Parkinson's disease, urged Californians to vote 'yes." "It could save the life of someone you love," says Fox in his advert, which first aired on 14 October.

The latest Field Poll, taken just after the ads began, showed $46 \%$ of Californians for

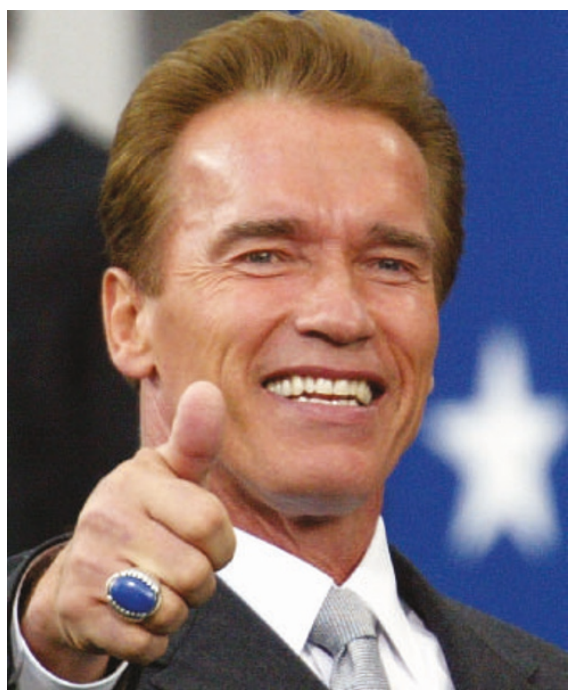

Governor Arnold Schwarzenegger has lent his weight to California's stem-cell initiative.

the initiative and 39\% against, indicating a slight increase in its popularity since August.

Proponents have lined up a long list of supporters, including dozens of patient advocacy organizations, business groups, medical associations and Nobel laureates. Several of the state's major newspapers have also lent their support, including the Los Angeles Times, the San Francisco Chronicle and The Mercury News. The Sacramento Bee is opposed.

Although initial opposition to the measure came largely from conservatives who object to embryo research on moral grounds, a number of liberal groups are now lining up against it on the grounds that it lacks adequate ethical safeguards against financial conflicts of interest (see Nature 431, 232; 2004).

"Stem-cell research needs controls and oversight. People in the progressive community have been saying that for a long time," says Susan Fogel, campaign coordinator for the ProChoice Alliance Against Proposition 71. The group's supporters include the National Women's Health Network and the California Nurses Association.

Objectors sparred with proponents before a 300-strong audience at a symposium in San Francisco on 12 October. The symposium was sponsored by former city mayor Willie Brown's Institute of Politics and Public Service. State senator Tom McClintock, a southern California Republican, said he was opposed on fiscal grounds. "I do not understand why it is suddenly the responsibility of California, with the lowest credit rating in the nation, to fund this research," he said.

But former secretary of state George Shultz, an influential Republican who now lives in San Francisco, countered that the state would benefit from the spending. "Basic research is very productive," he said. Shultz added that it would encourage businesses and researchers elsewhere to "come to California, where the action is".

\section{Germany balks at funding ESA's planetary ambitions}

Alison Abbott, Munich

Aurora, the European Space Agency's planetary exploration programme, may find itself in difficulties as France and Germany proved reluctant to support it last week.

Representatives of the agency's member states, meeting in Paris, heard that it had obtained commitments of between $€ 25$ million (US\$31 million) and $€ 30$ million. This is about half what the agency thought it would need to keep the programme going until it starts in earnest in 2006.

The shortfall is due to notable absences among the countries that have pitched in: Germany, in particular, has decided to withhold funding completely.

Europe is winding down its contribution to the International Space Station, and will instead focus on Aurora. The aim for the programme is to ensure that Europe maintains expertise in cutting-edge space technologies, so it can be an equal partner in any future international planetary exploration projects.

Launched in 2001, Aurora's preliminary projects are being updated in line with recent findings. Its long-term continuation must be approved by the agency's ministerial council at the end of next year.

Germany and France are the largest contributors to the European Space Agency (ESA). Together they account for more than half of its total budget: Germany paid $41 \%$ of Europe's bill for the International Space Station, for example. Costs for that project have hugely overrun, and Germany is still paying out. Together with France, Germany has also had to provide much of the increasingly hefty subsidy for Ariane launchers - the boosters that provide Europe with independent access to space. This independence from other agencies is fundamental to ESA policy.

Against this backdrop, Germany has decided to contribute nothing to Aurora. France has pledged a maximum of only $€ 2$ million and may also decide to give nothing when it makes its final decisions on financing at the end of this year. This puts Aurora in the uncomfortable position of being unsupported by ESA's two main players.

Surprisingly, Italy - the third largest contributor to ESA - has taken the lead and offered Aurora up to $€ 14$ million (see Nature 431, 619; 2004).

"We would like Germany to be able to join eventually, and hope for a higher contribution from France," says Aurora's director Daniel Sacotte, based at ESA's research and technology centre in Noordwijk, the Netherlands.

There are a few years yet for countries to change their minds. The first Aurora mission - a rover called ExoMars — is expected to launch no earlier than 2011. To fund this and other projects, Sacotte hopes for an annual budget of $€ 200$ million. But this could be extremely optimistic if major contributors do not jump back on board.

Scientists at Germany's space agency, the DLR, say that it is unlikely the country will be able to contribute to Aurora any time soon, as problems with the International Space Station continue. 